\title{
PROSES PENINGKATAN KETERLIBATAN KARYAWAN MELALUI GAYA KEPEMIMPINAN DAN MOTIVASI KERJA
}

(Studi Kualitatif terhadap Tenaga Perawat Unit Rawat Inap Anak di Balai Klinik Ibu \& Anak RKZ Malang)

\author{
Lianda Subekti $^{1}$, Margono Setiawan $^{2}$, Sudjanto $^{3}$ \\ Fakultas Ekonomi dan Bisnis Universitas Brawijaya ${ }^{123}$ \\ Email : $\underline{\text { liandasubketi@gmail.com }}$
}

\begin{abstract}
The aims of this study was to determine the process of increasing the employee engagement of the nurse children's unit in the Balai Klinik Ibu \& Anak RKZ Malang. This study used a qualitative approach with phenomenology design to explain the application of the leadership model hospital of directors and motivation of nurse children's unit in an effort to increase their engagement. Data were collected by interviewing 7 informants who are senior, intermediate and junior nursing staff. Data were analyzed using the Interactive Model of Analysis. The results showed that the application leadership model of hospital director for senior and intermediate nurses through the delegation of authority and involvement in decision-making; and for junior nurses through leading by example and description of vision and mission hospitals. Intrinsic motivation of nurses in the works are a live call and pride in their work, while extrinsic motivation is the incentive, salary, promotion, exchange office space, conducive working environment and good relationship between colleagues. The existence of unresolved conflicts between the hospital director with the senior nursing staff related to dissatisfaction in the distribution of incentives encouraging the increased desire to resign from the job and is more suited completed transactional leadership models.
\end{abstract}

Keywords: : employee engagement, leadership style, work motivation, nurse children's units, phenomenology design, qualitative approach

\begin{abstract}
Abstrak : Tujuan dari penelitian ini adalah untuk mengetahui proses peningkatan keterlibatan karyawan para tenaga perawat unit rawat inap anak di Balai Klinik Ibu \& Anak RKZ Malang. Penelitian ini menggunakan pendekatan kualitatif dengan desain fenomenologi untuk menjelaskan penerapan model kepemimpinan direktur rumah sakit dan motivasi kerja tenaga perawat unit rawat inap anak. Pengumpulan data dilakukan melalui wawancara terhadap 7 orang informan yang merupakan tenaga perawat senior, tenaga perawat menengah, tenaga perawat junior. Teknik analisis data menggunakan Interactive Model of Analysis. Hasil penelitian menunjukkan bahwa penerapan model kepemimpinan direktur rumah sakit bagi perawat senior dan menengah melalui pendelegasian wewenang dan keterlibatan dalam pengambilan keputusan; dan bagi tenaga perawat junior melalui memimpin melalui contoh dan penjabaran visi dan misi rumah sakit. Motivasi intrinsik tenaga perawat dalam bekerja adalah panggilan hidup dan kebanggaan dalam bekerja, sementara motivasi ekstrinsik adalah insentif, gaji, promosi jabatan, pertukaran tempat dinas, lingkungan kerja yang kondusif dan hubungan antar rekan kerja yang baik. Adanya konflik yang belum terselesaikan antara direktur rumah sakit dengan tenaga perawat senior terkait ketidakpuasan dalam pembagian insentif mendorong terjadinya peningkatan keinginan untuk mengundurkan diri dari pekerjaan dan lebih cocok diselesaikan dengan model kepemimpinan transaksional.
\end{abstract}

Kata Kunci: desain fenomenologi, gaya kepemimpinan, motivasi kerja, keterlibatan karyawan, pendekatan kualitatif, tenaga perawat unit rawat inap anak 


\section{PENDAHULUAN}

Rumah sakit merupakan suatu organisasi di bidang kesehatan yang memiliki banyak sumber daya manusia dalam memberikan pelayanan kesehatan kepada masyarakat. Sumber daya manusia yang terlibat dalam kegiatan operasional rumah sakit sangat beragam, mulai dari tenaga dokter, tenaga perawat dan tenaga kerja non-medis lainnya dan tidak terpisahkan satu sama lain dalam memberikan pelayanan kesehatan kepada masyarakat atau dengan kata lain harus saling bekerja sama. Secara khusus peran tenaga perawat sangat penting dalam suatu rumah sakit karena merupakan ujung tombak bagi kegiatan operasional rumah sakit dan juga merupakan sumber daya manusia yang paling lama melakukan kontak atau berhubungan dengan pasien yaitu selama 24 jam. Persepsi masyarakat mengenai tenaga perawat sebagai "one of us", yakni orang yang berjasa, cekatan, memberikan perhatian kepada orang lain, bekerja dengan hati, dapat dipercaya dan bersahabat, profesi sebagai tenaga perawat juga mempunyai sebuah tanggung jawab besar dalam memberikan pelayanan secara profesional.

Dalam suatu organisasi, harus diakui bahwa kelancaran kegiatan operasional dari suatu organisasi tidak terlepas dari bagaimana gaya kepemimpinan yang diimplementasikan oleh pimpinan. Burns (1978) dalam Ghafoor et al. (2011) menjelaskan bahwa gaya kepemimpinan transformasional mendukung saling pengertian antara karyawan dan sementara teori manajemen menjelaskan bahwa interaksi antara karyawan dan manajemen dikelola dengan cara-cara berbeda yang pada akhirnya mengarah di luar kepentingan diri karyawan dalam mendukung pencapaian tujuan organisasi. Bass (1999) melengkapi dalam tulisannya yang menjelaskan bahwa gaya kepemimpinan transformasional berisi empat komponen, yaitu karisma atau pengaruh ideal yang dikaitkan dengan perilaku, motivasi inspirasional, stimulasi intelektual, dan pertimbangan individual. Gaya kepemimpinan transformasional juga berfokus pada pengembangan dari bawahan dan kebutuhan mereka, sementara pada level manajer gaya kepemimpinan transformasional berfokus pada pengembangan sistem nilai karyawan dan memberikan motivasi bagi bawahan.

Salah satu faktor penting yang mendukung gaya kepemimpinan transformasional dalam suatu organisasi adalah adanya motivasi kerja yang dimiliki oleh karyawan, dimana karyawan yang termotivasi berarti akan tergerak untuk melakukan sesuatu. Robbins (2013: 237) mendefinisikan motivasi kerja sebagai suatu proses yang menjelaskan intensitas, arah, dan ketekunan usaha individu ke arah pencapaian tujuan organisasi. Motivasi kerja yang dimiliki karyawan dapat berasal dari dalam dirinya sendiri (secara intrinsik) dan berasal dari luar dirinya (secara ekstrinsik) yang dipengaruhi oleh gaya kepemimpinan transformasional dari atasannya. Luthans (2011: 166) menyebutkan bahwa faktor motivasi intrinsik bersifat nyata dan berhubungan dengan tugas atau pekerjaan itu sendiri, misalnya saja mencakup prestasi, penghargaan, promosi, tanggung jawab dan kesesuaian pekerjaan yang tampaknya berhubungan dengan kepuasan kerja. Sedangkan faktor motivasi ekstrinsik bersifat nyata dan dapat dilihat oleh orang lain seperti gaji (upah), hubungan antar pekerja, jaminan sosial, kondisi kerja dan kebijakan perusahaan.

Selain kepemimpinan transformasional dan adanya motivasi kerja, keterlibatan karyawan dalam organisasinya juga menjadi hal penting dalam keberlangsungan hidup organisasi. Suatu organisasi dapat berjalan dengan baik jika seluruh jajaran manajerial dan seluruh karyawan dapat bekerja sama dan berperan aktif dalam kegiatan operasional organisasi. Keterlibatan karyawan adalah sebuah konsep yang relatif baru dan faktor-faktor yang menghasilkan keterlibatan mungkin berbeda dengan orangorang yang menghasilkan hasil kerja yang lebih tradisional seperti kepuasan kerja dan komitmen organisasi. Seorang karyawan terlibat melakukan pekerjaan dengan timnya untuk meningkatkan kinerja dan tujuan organisasi, dimana orang-orang yang terlibat selalu melaksanakan tugasnya secara fisik, kognitif dan emosional (Kahn, 1990 dalam Azoury et al., 2012).

Hubungan antara pola kepemimpinan transformasional, motivasi kerja dan keterlibatan karyawan masih belum banyak dilakukan penelitian secara mendalam sehingga menarik perhatian untuk dilakukan pengembangan penelitian lebih lanjut. Keterkaitan antara kepemimpinan transformasional dan motivasi kerja seperti dikemukakan dalam jurnal milik Nazari et al. (2011) menunjukan bahwa manajer sangat mempengaruhi motivasi mereka dalam bekerja, didukung dengan faktor-faktor lain termasuk struktur organisasi dan budaya, faktor sosial, 
keamanan finansial dan sifat pekerjaan keperawatan yang dilakukan. Hal ini didukung oleh penelitian yang dilakukan oleh Linton dan Farrell (2013) yang menyebutkan bahwa para perawat termotivasi untuk bekerja jika pimpinan langsung memberikan contoh (leading by example), adanya komunikasi antara pimpinan dan bawahan, kesempatan untuk mengembangkan diri, pemahaman terhadap para bawahan dan keberanian pengambilan keputusan di masa krisis. Tsounis et al. (2014) melengkapi pernyataan tersebut melalui penelitiannya dan menemukan bahwa faktorfaktor eksternal seperti upah yang tinggi dan sistem insentif tidak mendorong peningkatan motivasi kerja para tenaga medis, namun faktor pengakuan diri dalam lingkungan kerja dan kesempatan pengembangan diri yang diberikan oleh pimpinan lebih mendorong motivasi mereka dalam bekerja.

Kepemimpinan transformasional dianggap sebagai bentuk gaya kepemimpinan yang paling ideal dalam meningkatkan motivasi kerja dan keterlibatan karyawan dalam sebuah organisasi. Akan tetapi tidak semua organisasi cocok untuk dikelola dengan pola kepemimpinan ini. Penelitian yang dilakukan oleh Fernandez (2011) menyebutkan bahwa gaya kepemimpinan transformasional yang diterapkan oleh pimpinan bukan menjadi faktor utama para tenaga perawat kurang berperan aktif dalam pekerjaannya, namun nominal gaji yang kecil, tidak adanya kesempatan mengembangkan diri, kurangnya waktu dengan keluarga dan lingkungan kerja yang tidak kondusif menjadi faktor-faktor yang menyebabkan tenaga perawat bersikap pasif dalam lingkungan kerja hingga akhirnya memutuskan untuk berhenti bekerja. Beberapa hasil penelitian sebelumnya masih terdapat inkonsistensi terkait hubungan kepemimpinan transformasional dan motivasi kerja dalam upaya peningkatan keterlibatan karyawan dalam bekerja. Penelitian ini dikembangkan dari penelitian-penelitian sebelumnya (Nazari et al., 2011; Linton dan Farrell, 2013; Tsounis et al., 2014; dan Fernandez, 2011) yang melakukan penelitian pada lingkup kota besar dan dilakukan dengan pendekatan kualitatif dan mixed method. Penelitian ini secara spesifik mencoba untuk menggali lebih mendalam dan menggambarkan proses kepemimpinan transformasional dan motivasi kerja dalam meningkatkan keterlibatan tenaga perawat dalam bekerja, khususnya pada tenaga perawat unit rawat inap anak yang menangani berbagai macam kelas rawat inap anak.

Objek dalam penelitian ini adalah tenaga perawat unit rawat inap anak di Balai Klinik Ibu \& Anak (BKIA) RKZ Malang. Adanya pergantian direktur rumah sakit, perubahan peraturan, tuntutan kerja yang tinggi, serta karakteristik personal pasien yang berbeda-beda tentunya menuntut ketangkasan dan sikap proaktif para tenaga perawat dalam bekerja yang dipengaruhi oleh motivasi kerja secara intrinsik yang dimiliki oleh masing-masing individu tenaga perawat dan motivasi ekstrinsik yang dilakukan oleh kepala unit keperawatan dan direktur rumah sakit sendiri. Kepala unit keperawatan sebagai perpanjangan tangan dan perantara dari direktur rumah sakit untuk mengkoordinasi, mengakomodasi dan mengarahkan tenaga perawat unit rawat inap anak dalam memberikan pelayanan kepada masyarakat untuk mencapai visi, misi dan tujuan rumah sakit. Pemilihan key informants untuk penelitian ini difokuskan pada tenaga perawat unit rawat inap dan secara khusus mengambil key persons tenaga perawat unit rawat inap anak pada masing-masing kelas sebanyak 3 hingga 5 orang sesuai dengan jenjang senioritas. Selain mengambil key persons para tenaga perawat unit rawat inap anak, penelitian ini juga mengambil key persons direktur rumah sakit dan kepala keperawatan sebagai bagian dari Focus Group Discussion (FGD) dalam pengumpulan data yang lebih maksimal.

\section{PREPOSISI PENELITIAN}

Berdasarkan penjelasan di atas, maka dalam penelitian ini diambil beberapa preposisi penelitian sebagai berikut:

Preposisi 1 : Pemberian masukan, semangat, arahan, dan kesempatan untuk mengembangkan diri yang diberikan oleh direktur rumah sakit mendorong peningkatan motivasi kerja tenaga perawat unit rawat inap anak.

Preposisi 2 : Hubungan personal yang baik, dukungan dari direktur rumah sakit dan penghargaan atas kinerja yang sudah dilakukan semakin mendorong tenaga perawat unit rawat inap anak untuk terlibat dalam pekerjaannya.

Preposisi 3 : Rasa bangga terhadap pekerjaan, pengakuan di tempat kerja, lingkungan kerja yang kondusif, gaji yang besar dan menjadi motivasi intrinsik dan motivasi ekstrinsik tenaga perawat unit rawat inap anak untuk meningkatkan keterlibatannya dalam pekerjaan. 
Preposisi 4 : Promosi jabatan, hubungan sesama rekan kerja yang baik, kenyamanan di tempat kerja dan koordinasi pekerjaan yang baik menjadi motivasi tenaga perawat unit rawat inap anak untuk terlibat dalam pekerjaannya.

\section{METODE PENELITIAN}

Penelitian ini dilakukan dengan menggunakan pendekatan kualitatif dengan desain fenomenologi yang merupakan suatu studi yang berusaha mencari "esensi" makna dari suatu fenomena yang dialami oleh beberapa individu (Creswell, 2015: 105). Lokasi penelitian ini dilakukan di Balai Klinik Ibu \& Anak (BKIA) RKZ Malang di Jl. Nusa Kambangan No.56 Malang. Key informants dalam penelitian ini adalah tenaga perawat unit rawat inap anak dan secara khusus mengambil key persons tenaga perawat senior, tenaga perawat menengah dan tenaga perawat junior dari masing-masing kelas rawat inap. Penelitian ini juga menggunakan Focus Group Discussion (FGD) direktur rumah sakit dan kepala keperawatan. Sumber data dalam penelitian ini adalah data primer dan data sekunder, serta menggunakan teknik pengumpulan data melalui wawancara mendalam, observasi dan studi dokumentasi (Myers, 2009: 130). Analisis data dalam penelitian ini menggunakan Interactive Model of Analysis oleh Miles dan Hubberman (dalam Sutopo, 2002: 196) yang terdiri dari pengumpulan data, reduksi data, penyajian data dan penarikan kesimpulan.

\section{HASIL PENELITIAN DAN PEMBAHASAN}

Penelitian ini mengambil informasi dari 7 orang informan, yaitu Ibu SL (perawat senior di kelas VIP), Ibu RN (perawat senior di kelas I), Ibu TR (perawat menengah di kelas I), Ibu ST (perawat senior di kelas II), Ibu MR (perawat junior di kelas II), Ibu NN (perawat menengah di kelas III) dan Mas JF (perawat junior di kelas III). Hasil dan pembahasan dalam penelitian ini sebagai berikut:

\section{Kepemimpinan Transformasional Sebagai Pendorong Motivasi Kerja Tenaga Perawat}

Penerapan model kepemimpinan transformasional oleh direktur rumah sakit dalam sebagai pendorong motivasi kerja tenaga perawat unit rawat inap anak di Balai Klinik Ibu \& Anak (BKIA) RKZ Malang berbeda-beda untuk masing-masing tenaga perawat. Implementasi kepemimpinan transformasional yang dilakukan direktur RS kepada tenaga perawat junior melalui pemberian semangat dan masukan, cerita pengalaman pengelolaan rumah sakit dan penjabaran visi dan misi rumah sakit. Penjabaran visi dan misi rumah sakit yang dilakukan oleh direktur RS bertujuan untuk memberikan penjelasan yang lebih mendalam mengenai lingkungan kerja RS bagi tenaga perawat junior, dan hal tersebut menunjukan bahwa direktur RS mampu menjadi pemimpin yang visioner. Hal tersebut sesuai dengan pendapat Hogg (2012) bahwa pemimpin transformasional yang visioner mampu menjelaskan dan menerapkan pengaturan misi organisasi yang realistis dan ringkas, pengaturan visi, dan nilai-nilai yang sesuai dengan budaya organisasi.

Bagi tenaga perawat senior dan tenaga perawat menengah, bentuk kepemimpinan transformasional yang dilakukan oleh direktur rumah sakit diwujudkan dalam pendelegasian wewenang dan melibatkan para tenaga perawat senior atau tenaga perawat menengah dalam pengambilan keputusan. Pendelegasian wewenang dan melibatkan tenaga perawat dalam proses pengambilan keputusan menunjukan direktur RS mendorong adanya inovasi dan kreativitas dari bawahannya. Seperti yang dikemukakan oleh Bass dan Avolio (1993), seorang pemimpin transformasional mendorong upaya bawahan untuk menjadi inovatif dan kreatif dengan mempertanyakan asumsi, pembingkaian ulang masalah dalam organisasi, dan mendekati situasi dengan cara-cara baru. Hal ini didukung oleh teori yang dikemukakan oleh Hogg (2012) bahwa pemimpin transformasional juga bersedia untuk mendengarkan dan menerima ide-ide baru dan memahami bahwa kesuksesan adalah usaha bersama dan pertumbuhan berasal dari kesediaan untuk terbuka dan mendengarkan gagasan dari semua tingkat organisasi.

\section{Kepemimpinan Transformasional dalam Upaya Mendorong Peningkatan Keterlibatan Kerja Tenaga Perawat}

Pemimpin transformasional dalam suatu organisasi tidak hanya memberikan motivasi kepada bawahannya, namun juga berupaya untuk melakukan peningkatan keterlibatan kerja bawahannya, misalnya saja dengan menciptakan suasana kerja yang kondusif hingga nantinya akan menyebabkan bawahannya merasakan suatu keterikatan terhadap lingkungan kerjanya. Pemimpin juga harus memiliki kemampuan untuk menangkap kepala, hati, dan jiwa dari 
karyawan untuk menanamkan keinginan intrinsik dan semangat untuk mencapai keunggulan tertentu. Berdasarkan wawancara yang dilakukan, para informan menyatakan bahwa hubungan antar sesama rekan kerja terjalin dengan baik, lingkungan kerja yang kondusif dan respon direktur rumah sakit terhadap permasalahan dalam pekerjaan semakin meningkatkan keterlibatan kerja mereka di lingkungan kerja.

Secara spesifik bagi tenaga perawat senior dan tenaga perawat menengah, bentuk supervisi yang dilakukan direktur, respon direktur terhadap permasalahan yang dihadapi oleh bawahan di lingkungan kerja dan bentuk hubungan direktur dengan para bawahan cenderung pada posisi fluktuatif. Para tenaga perawat senior dan menengah menyatakan bahwa bentuk supervisi yang dilakukan oleh direktur rumah sakit dan respon terhadap permasalahan di lingkungan cenderung netral. Supervisi yang dilakukan oleh direktur rumah sakit lebih banyak dilakukan melalui kepala keperawatan dan kepala unit anak sebagai perpanjangan tangan. Sementara itu, bagi tenaga perawat junior bentuk supervisi yang dilakukan oleh direktur rumah sakit sudah maksimal. Supervisi yang diberikan tidak selalu langsung dari direktur rumah sakit terhadap bawahannya, namun melalui kepala keperawatan dan kepala unit anak. Direktur rumah sakit mendelegasikan wewenang kepada kepala keperawatan dan kepala unit anak, hal ini sesuai dengan prinsip pendelegasian wewenang menurut Mangkunegara (2010), dimana direktur memberikan wewenang pada bawahannya untuk sewaktu-waktu dapat mengambil keputusan terhadap pekerjaan yang dilakukan. Pendelegasian wewenang menunjukan bahwa direktur rumah sakit memberikan kesempatan bagi bawahannya untuk berkembang dan berani terlibat dalam pengambilan keputusan.

\section{Bentuk Motivasi Kerja dalam Mendorong Peningkatan Keterlibatan Kerja Tenaga Perawat}

Motivasi kerja merupakan suatu unsur yang harus dimiliki oleh setiap sumber daya manusia. Motivasi kerja yang dimiliki oleh tenaga perawat unit rawat inap anak dapat berasal dari dalam diri sendiri (secara intrinsik) dan berasal dari faktor di luar diri sendiri (secara ekstrinsik). Motivasi-motivasi tersebut sesuai dengan teori motivasi Herzberg (1959), yaitu teori dua faktor yang meliputi faktor-faktor satisfier atau intrinsik (prestasi, pengakuan akan kontribusi, pekerjaan itu sendiri, tanggung jawab dan kemajuan) dan faktor-faktor hygiene atau dissatisfier (secara ekstrinsik termasuk hubungan antar personal, kebijakan perusahaan, pengawasan, gaji atau upah dan kondisi lingkungan kerja). Hasil wawancara yang dilakukan terhadap para informan memperoleh jawaban yang bermacam-macam, dimana motivasi terbesar yang mendorong para informan untuk proaktif terlibat di lingkungan kerja secara intrinsik yaitu rasa tanggung jawab terhadap pekerjaan dan menyangkut pekerjaan itu sendiri. Sedangkan motivasi ekstrinsik yang mendorong para tenaga perawat yaitu gaji yang diperoleh serta kondisi lingkungan kerja yang kondusif. Adanya rasa tanggung jawab dalam pekerjaan dan kesenangan terhadap pekerjaan itu sendiri menunjukan bahwa terdapat keterikatan secara psikologis terhadap pekerjaannya tersebut. Keterikatan secara psikologis tersebut nantinya akan mendukung para tenaga perawat untuk semakin aktif terlibat di dalam pekerjaannya dan termotivasi untuk memperoleh kinerja yang lebih baik (Mercer, 2007; AON Hewitt, 2015).

Di sisi lain, faktor insentif masih menjadi salah satu alasan yang mendorong tenaga perawat untuk terlibat dalam pekerjaannya. Pemberian insentif terhadap bawahan merupakan bentuk perhatian dan penghargaan yang diberikan oleh suatu organisasi terhadap sumber daya manusia yang ada di dalamnya. Di Balai Klinik Ibu \& Anak (BKIA) RKZ Malang memberikan insentif terhadap para sumber daya manusia yang bekerja, namun hanya tenaga perawat dengan masa kerja di atas 1 tahun yang menerima insentif. Akan tetapi, hasil penelitian menemukan bahwa ada ketidakpuasan dari tenaga perawat senior di unit rawat inap anak mengenai insentif yang menjadi hak mereka. Hasil wawancara terhadap lima orang informan dengan masa kerja di atas 8 tahun tersebut menyatakan bahwa di dalam organisasinya terjadi permasalahan dalam pembagian insentif. Permasalahan yang dihadapi adalah tersendatnya pembagian insentif selama satu tahun terakhir dan hal tersebut menyebabkan semangat dalam bekerja mengalami sedikit penurunan. Keinginan tenaga perawat untuk memperoleh insentif sebagai tambahan pemasukan menunjukan bahwa insentif masih menjadi motivasi ekstrinsik utama, selain pemberian gaji atau upah, yang mendorong tenaga perawat untuk terlibat di dalam 
pekerjaannya. Hal ini diperkuat dengan penelitian Swinton-Douglas (2010) yang menegaskan pentingnya pemenuhan kebutuhan karyawan dan pemimpin untuk meningkatkan keterlibatan mereka dalam organisasi, dan faktor insentif serta penghargaan semakin memacu mereka untuk proaktif terlibat di tempat kerja.

\section{Bentuk Kepemimpinan Transformasional dan Motivasi Kerja dalam Mendorong Peningkatan Keterlibatan Kerja Tenaga Perawat}

Kepemimpinan transformasional dan motivasi kerja merupakan dua unsur penting yang dapat mendorong peningkatan keterlibatan kerja sumber daya manusia dalam suatu organisasi. Pemimpin transformasional menciptakan hubungan yang baik dengan bawahannya, mendorong terciptanya ikatan secara emosional yang timbul dari hubungan bawahan dengan organisasinya. Hal tersebut didukung oleh penelitan yang dilakukan oleh Zhang et al. (2014) bahwa keterlibatan karyawan melibatkan interaksi tiga faktor, yaitu komitmen kognitif, komitmen emosional, dan hasil perilaku yang timbul dari hubungan karyawan dengan organisasinya. Berdasarkan hasil diwawancara menyatakan bahwa bentuk penghargaan yang diberikan oleh pihak rumah sakit umumnya berupa penghargaan sebagai tenaga perawat terbaik, adanya promosi jabatan, rolling tempat dinas ke kelas perawatan yang lebih tinggi dan kesempatan untuk berlibur ke luar kota dan dilakukan secara bersama-sama dengan seluruh karyawan. Promosi jabatan dan pertukaran tempat dinas bergantung pada kebijakan dari direktur rumah sakit, namun salah satu informan menyatakan pernah memperoleh penghargaan dari rumah sakit berupa rolling tempat dinas.

Merekomendasikan tempat kerja kepada orang lain merupakan salah satu unsur "say" dari model keterlibatan karyawan menurut AON Hewitt (2015). Berdasarkan hasil wawancara yang diperoleh, dapat dikatakan bahwa tenaga perawat di unit rawat inap anak Balai Klinik Ibu \& Anak (BKIA) RKZ Malang bersedia merekomendasikan tempatnya bekerja kepada orang lain yang sedang mencari pekerjaan. Ada tidaknya keinginan untuk resign merupakan bentuk operasional dari "stay" dalam model keterlibatan karyawan menurut AON Hewitt (2015). Terkait keinginan untuk keluar dari pekerjaan (resign) dan keinginan untuk merekomendasikan tempat kerja kepada orang lain dan inspirasi dari direktur rumah sakit, hasil wawancara yang dilakukan terhadap semua informan menghasilkan jawaban yang beragam. Beberapa orang responden cenderung menyatakan bahwa mereka memiliki keinginan untuk resign dari pekerjaan namun masih memiliki beberapa pertimbangan lain sebelum benar-benar mengambil keputusan tersebut. Unsur terakhir dalam model keterlibatan karyawan AON Hewitt (2015) adalah "strive", yang dalam penelitian ini diwujudkan dalam bentuk menggali pendapat para informan terkait inspirasi dari direktur rumah sakit untuk bekerja lebih keras setiap hari. Dari hasil wawancara yang dilakukan, para informan menyatakan bahwa mereka sudah bekerja keras setiap harinya tanpa perlu memperoleh inspirasi tambahan dari direktur rumah sakit.

\section{Konflik Terpendam di Lingkungan Balai Klinik Ibu \& Anak (BKIA) RKZ Malang}

Adanya tuntutan dari tenaga perawat senior dan menengah terhadap direktur rumah sakit terkait dengan pembagian insentif berdampak pada penurunan tingkat keterlibatan mereka dalam pekerjaan. Para tenaga perawat senior dan menengah tersebut menuntut agar insentif mereka dibagikan karena sudah menjadi hak mereka, namun sebelum adanya pembagian insentif tersebut maka pekerjaan yang mereka lakukan hanya sebatas pada pemenuhan kewajiban. Hal ini menunjukan bahwa faktor pembagian insentif menjadi motivasi ekstrinsik yang cukup besar agar para tenaga perawat senior dan menengah mau meningkatkan keterlibatan mereka dalam pekerjaan. Pemberian insentif kepada para tenaga perawat senior dan menengah menjadi bentuk transaksi dengan direktur rumah sakit. Dalam hal ini, bentuk kepemimpinan transaksional dari direktur rumah sakit perlu diterapkan untuk mendorong para tenaga perawat senior dan menengah proaktif terlibat dalam lingkungan kerja.

Penerapan model kepemimpinan transformasional tidak sesuai dengan tuntutan tenaga perawat senior dan menengah terkait dengan insentif yang belum mereka peroleh. Meski pun model kepemimpinan transformasional dianggap sebagai model kepemimpinan yang paling ideal, namun dalam hal tertentu model kepemimpinan transaksional lebih sesuai untuk diterapkan. Adanya konflik yang belum terselesaikan terkait dengan insentif menunjukan bahwa direktur rumah sakit dan 
tenaga perawat senior serta tenaga perawat menengah harus berkompromi untuk menyelesaikan konflik tersebut. Direktur rumah sakit harus mampu menyelesaikan konflik tersebut meski pun dengan menerapkan model kepemimpinan transformasional untuk mendorong tenaga perawat senior dan menengah semakin aktif terlibat dalam pekerjaan.

\section{Alur Proses Peningkatan Keterlibatan Kerja Tenaga Perawat Unit Rawat Inap Anak}

Berdasarkan hasil pembahasan di atas, maka alur proses peningkatan kerja tenaga perawat di Balai Klinik Ibu \& Anak (BKIA) RKZ Malang dapat digambarkan seperti Gambar 1 di bawah ini:

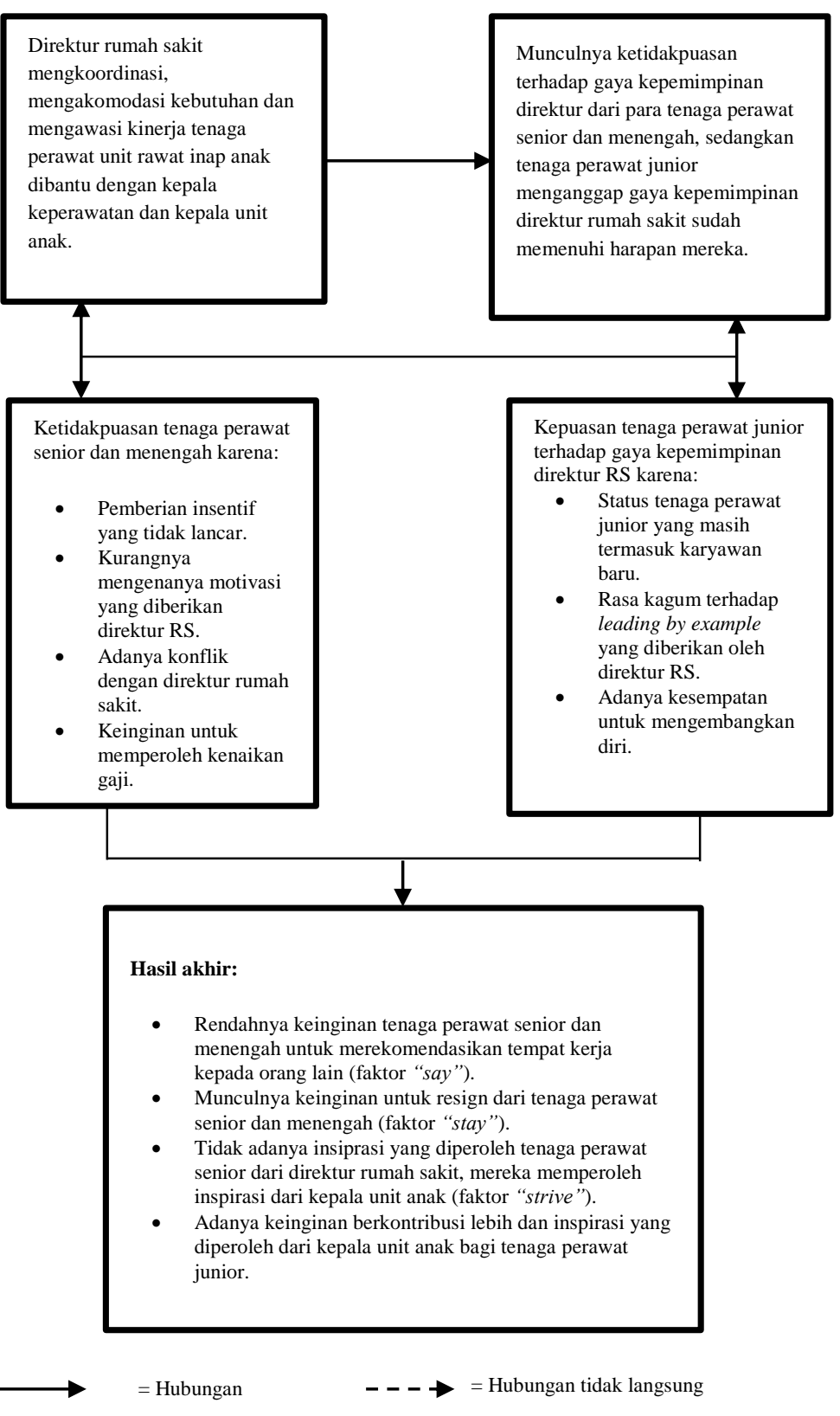

\section{PROPOSISI PENELITIAN}

Berdasarkan hasil penelitian dan pembahasan yang sudah dilakukan, maka dalam penelitian ini dapat disimpulkan beberapa preposisi penelitian sebagai berikut:

Proposisi 1 : Pemberian masukan, leading by example dan penjabaran visi dan misi rumah sakit mendorong peningkatan motivasi kerja tenaga perawat junior sedangkan pendelegasian wewenang dan melibatkan bawahan dalam pengambilan keputusan mendorong peningkatan motivasi kerja tenaga perawat senior dan menengah.

Proposisi 2 : Hubungan antar sesama rekan kerja yang baik, lingkungan kerja yang kondusif dan respon direktur rumah sakit terhadap permasalahan dalam pekerjaan semakin meningkatkan keterlibatan tenaga perawat unit rawat inap anak.

Proposisi 3 : Timbulnya panggilan dalam hidup untuk menjadi perawat, adanya rasa bangga terhadap pekerjaan, dan lingkungan kerja yang kondusif menjadi motivasi intrinsik dan motivasi ekstrinsik tenaga perawat unit rawat inap anak untuk proaktif terlibat dalam pekerjannya. Secara khusus bagi tenaga perawat senior, pemberian insentif juga menjadi motivasi ekstrinsik.

Proposisi 4 : Promosi jabatan, rolling tempat dinas, pemberian bonus liburan, kenyamanan di tempat kerja dan koordinasi pekerjaan yang baik mendorong tenaga perawat unit rawat inap proaktif terlibat dalam pekerjaannya. Secara khusus pada tenaga perawat senior muncul keinginan untuk resign karena adanya konflik yang belum terselesaikan dengan direktur rumah sakit.

\section{KESIMPULAN DAN SARAN \\ Kesimpulan}

Berdasarkan pembahasan dan pembentukan proposisi di atas, dapat diambil kesimpulan bahwa dalam proses kepemimpinan transformasional dalam meningkatkan motivasi kerja para tenaga perawat unit rawat inap anak di Balai Klinik Ibu \& Anak (BKIA) RKZ Malang bagi tenaga perawat senior dan menengah melalui pendelegasian wewenang dan kebijakan melibatkan mereka dalam pengambilan keputusan menjadi pendorong motivasi dalam bekerja. Sementara bagi tenaga perawat junior melalui pemberian masukan, leading by example dan penjabaran visi dan misi rumah sakit. Bentuk motivasi intrinsik yang menjadi daya pendorong peningkatan 
keterlibatan kerja tenaga perawat unit rawat inap anak adalah adanya panggilan dalam hidup untuk menjadi perawat dan adanya rasa kebanggaan serta kecintaan terhadap pekerjaan. Motivasi ekstrinsik yang menjadi daya pendorong adalah lingkungan kerja yang kondusif dan bagi tenaga perawat senior pemberian insentif juga menjadi motivasi ekstrinsik mereka untuk semakin proaktif terlibat di dalam pekerjaannya. Sementara dalam meningkatkan keterlibatan kerja para tenaga perawat unit rawat inap anak dapat dilakukan melalui pemberian promosi jabatan, rolling tempat dinas, pemberian bonus liburan, kenyamanan di tempat kerja dan koordinasi pekerjaan yang baik.

\section{Saran}

Berdasarkan penelitian yang sudah dilaksanakan dan penarikan kesimpulan di atas, maka peneliti dapat memberikan saran bagi penelitian berikutnya, diharapkan peneliti lain dapat mengeksplorasi lebih mendalam mengenai bentuk kepemimpinan lainnya dan motivasi kerja pada tenaga medis di unit-unit perawatan lain dan di rumah sakit pemerintah dan menjadi tambahan referensi bagi peneliti lain untuk mengeksplorasi mengenai proses peningkatan keterlibatan kerja sumber daya manusia dalam suatu organisasi.

Bagi Balai Klinik Ibu \& Anak (BKIA) RKZ Malang, peneliti memberikan masukan agar pihak pimpinan rumah sakit lebih memperhatikan hal-hal yang memotivasi tenaga perawat untuk semakin aktif terlibat di lingkungan kerja. Hal tersebut terjadi dikarenakan adanya perbedaan motivasi yang mendasari tenaga perawat senior dan menengah serta tenaga perawat junior dalam melibatkan diri di dalam pekerjaannya. Dengan memperhatikan hal-hal yang menjadi motivasi tenaga perawat dalam bekerja, maka direktur rumah sakit dapat memotivasi tenaga perawat unit rawat inap anak berbeda-beda sesuai dengan jenjang senioritasnya. Peneliti juga memberikan saran agar direktur rumah sakit melakukan penyelesaian konflik dengan tenaga perawat senior dan menengah. Penyelesaian konflik dapat dilakukan dengan memberikan insentif yang sudah menjadi tenaga perawat tersebut. Di sisi lain, direktur rumah sakit juga seyogyanya membuka dialog dengan para tenaga perawat agar memahami apa yang menjadi keinginan dan kebutuhan dari bawahannya tersebut.
DAFTAR PUSTAKA

AON Hewitt. 2015. Aon's Hewitt Model of Employee Engagement.

Azoury, A., Daou,L., \& Sleiaty, F. 2014. Employee Engagement In Family And Non-Family Firms. International Strategic Management Review, 1(1-2), 11-29.

Bass, B.M., \& Steidlmeier, P. 1999. Etics, Character, and Authentic Transformational Leadership Behavior. Leadership Quaterly, 10(2).

Creswell, John W. 2015. Qualitative Inquiry and Research Design: Choosing Among Five Approaches, $3^{\text {rd }}$ Edition. London: Sage Publication. Lazuardi, Ahmad Lintang (Penerjemah). 2015. Penelitian Kualitatif \& Desain Riset: Memilih di Antara Lima Pendekatan. Edisi Pertama. Yogyakarta: Pustaka Pelajar.

Fernandez, David. 2011. Employee Retention And Transformational Leadership: A Phenomenological Study. Dissertation. Doctor of Business Administration. University of Phoenix, USA.

Ghafoor, A., Qureshi, T.M., Khan, M.A., \& Hijazi, S.T. 2011. Transformational Leadership, Employee Engagement and Performance: Mediating Effect of Psychological Ownership. African Journal of Business Management, 5(17), 7391-7403. Doi: 10.5897/AJBM11.126.

Hogg, Bill. 2012. 10 Characteristics of Transformational Leaders.

Linton, Jenelle \& Farrell, Maureen J. 2013. Nurses' Perceptions of Leadership In An Adult Intensive Care Unit: A Phenomenology Study. Intensive and Critical Care Nursing, 25(2), 64-71. doi:

Luthans, Fred. 2011. Organizational Behavior, $12^{\text {th }}$ Edition. New York : McGraw Hill.

Mangkunegara, Anwar P. 2010. Manajemen Sumber Daya Manusia Perusahaan. Bandung: PT. Remaja Rosdakarya.

Myers, M.D. 2009. Qualitative Research in Business and Management. London : Sage Publication.

Nazari, A., Nayeri, D., Salsali, M., \& Ahmadi, F. 2011. Iranian Staff Nurses' Views of Their Productivity And Human Resource Factors Improving And Impeding It: A Qualitative Study. Human Resource for Health, 3(1), 11-11. Doi: doi: 10.1186/1478-4491-3-9 
Robbins, Stephen P. 2013. Organizational

Behavior, $15^{\text {th }}$ Edition. New York: McGraw Hill.

Sutopo. 2002. Metodologi Penelitian Kualitatif. Surakarta: Sebelas Maret University Press.

Tsounis, A., Sarafis, P., \& Bamidis, P. 2014. Motivation Among Physicians in Greek Public Health Care Sector. British Journal of Medicine \& Medical Research, 4(5): 1094-1105. 